\title{
PENGABDIAN KKN-MANDIRI DESA GOLO WUAS KABUPATEN MANGGARAI TIMUR
}

\author{
Daniel Wolo ${ }^{1 *}$, Yulius Saprianus Dala Ngapa ${ }^{2}$, Marıa L.S. Harıyanti ${ }^{3}$ \\ 1,2,3 Universitas Flores, Ende, Indonesia \\ *Penulis Koresponsensi, email: dewolochem@gmail.com
}

Article History

Received:03/11/2020

Revised:7/11/2020

Accepted:15/11/2020

\begin{abstract}
The Independent Real Work Lecture (KKN) program has been implemented in Golo Wuas Village, Elar Selatan District, East Manggarai Regency. The purpose of implementing the program is that lecturers and students gain learning experiences through direct involvement with the community by finding, formulating, solving, and overcoming problems in the field. The method of implementing KKN activities is carried out in the form of data collection, socialization, and training involving the government and the community directly. Some of the results achieved from this Independent Community Service Program are some of the activities that have been carried out (a) Assistance in teaching and learning activities in mathematics subjects to SDK Ndawang students, (b) Counseling and parquetry of making husk charcoal fertilizer and organic fertilizer, (c) empowerment seminars community in the health sector
\end{abstract}

Keywords: Independent Community Service, Compost Fertilizer, Organic Fertilizer, Empowerment Seminar, Learning Model

\begin{abstract}
Abstrak. Telah dilaksanakan program Kuliah Kerja Nyata (KKN) Mandiri di Desa Golo Wuas, Kecamatan Elar Selatan, Kabupaten Manggarai Timur. Tujuan dari pelaksanaan program yaitu Dosen dan mahasiswa memperoleh pengalaman belajar melalui keterlibatan dengan masyarakat secara langsung dengan menemukan, merumuskan, memecahkan dan menanggulangi permasalahan yang berada dilapangan. Metode pelaksanaan kegiatan KKN dilakukan dalam bentuk pengumpulan data, sosialisasi dan pelatihan melibatkan pemerintah dan masyarakat secara langsung. Beberapa hasil yang dicapai dari kegiatan KKN Mandiri ini adalah Beberapa kegiatan yang telah dilaksanakan (a) Pendampingan kegiatan belajar mengajar mata pelajaran matematika pada peserta didik SDK Ndawang, (b) Penyuluhan dan praktek pembuatan Pupuk arang sekam dan pupuk organik, (c) Seminar pemberdayaan masyarakat dalam bidang kesehatan.
\end{abstract}

Kata Kunci : KKN mandiri, Pupuk kompos, Pupuk Organik, Seminar Pemberdayaan, Model Pembelajaran

How to Cite: Wolo, D., Ngapa , Y. S. D. ., \& Hariyanti, M. L. . (2020). PENGABDIAN KKN-MANDIRI DESA GOLO WUAS KABUPATEN MANGGARAI TIMUR. Mitra Mahajana: Jurnal Pengabdian Masyarakat, 1(1), 24-31. https://doi.org/10.37478/mahajana.v1i1.715

\section{PENDAHULUAN}

Pandemi Covid 19 yang melanda dunia telah mempengaruhi berbagai aspek kehidupan salah satunya dalam dunia akademik. Universitas Flores sebagai salah satu institusi pendidikan di Flores ikut merasakan dampak tersebut. mengikuti instruksi Kemeneristekdikti, pelaksanaan KKN tahun 2020 dilakukan secara mandiri di lokasi mahasiswa tinggal atau berdomisili. Desa Woo Guas berlokasi di Kecamatan Elar Selatan Kabupaten Manggarai Timur. Meiliki luas wilayah $17.2 \mathrm{~km}^{2}$, topografi desa ini terdiri atas lereng, perbukitan serta terdapat kawasan hutan. Desa Golo Wuas berada pada ketinggian 700-1100 m, paling tinggi dibandingkan desa disekitarnya. Desa ini berjarak sekitar $60 \mathrm{~km}$ dari ibu kota kabupaten, Borong. Terdapat 4 Dusun, 6 RW dan 17 RT. Pada tahun 2019 penduduk Desa Golo wuas berjumlah 2298 dengan rindcian 1119 laki-laki dan 1179 perempuan. Terdapat 3 Sekolah Dasar dengan rincian 1 SD Inpres, 1 SD Swasta, dan 1 SD Negeri dengan total jumlah peserta didik 213 siswa yang dibimbing 23 guru. Hanya terdapat satu SMP Negeri sedangkan untuk tingkat SMA belum ada. Untuk sarana prasarana atau fasilitas kesehatan sudah terdapat 3 posyandu dengan tenaga 2 perawat, 3 bidan dan 15 tenaga kader yang diperbantukan di Desa. Desa ini berbatasan dengan : 
Tabel 1. Batas desa Golo Wuas

\begin{tabular}{lll}
\hline \multicolumn{1}{c}{ Batasan } & \multicolumn{1}{c}{ Desa/Kelurahan } & \multicolumn{1}{c}{ Kecamatan } \\
\hline Sebelah barat & Teno Mese & Elar selatan \\
Sebelah timur & Sipi & Elar Selatan \\
Sebelah utara & Compang Congkar & Sambi Rampas \\
Sebelah selatan & Golo Nderu & Kota Komba \\
\hline
\end{tabular}

Mayoritas penduduk Desa Golo Wuas memiliki matapencaharian bertani dan berkebun selain itu juga menggembalakan hewan ternak seperti sapi, kerbau, babi, kambing dan kuda. Karena ketiadaan tower untuk jaringan telepon maka akses komunikasi di desa ini cukup sulit. Transporatsi untuk menuju desa juga hanya dilayani oleh satu mobil angkutan penumpang (BPS Manggarai Timur 2020).

Dalam kaitannya dengan kegiatan KKN, mahasiswa diajak untuk meneliti dan merumuskan masalah yang kompleks, menelaah potensi-potensi dan kelemahan dalam masyarakat dan merumuskannya. Dengan makin tingginya ilmu pengetahuan dan teknologi, maka mahasiswa dituntut untuk mengembangkan ilmu pengetahuan agar dapat berdaya dan berhasil guna. Oleh karena itu, teori yang didapatkan dari bangku kuliah diharapkan dapat diterapkan di lapangan. Pengetahuan teoritis belumlah dapat memberikan gambaran yang konkret jika belum diterapkan di lapangan (Syardiansyah, 2017)

\section{METODE PELAKSANAAN}

Kuliah Kerja Nyata (KKN) tematik integratif dengan tema umum "Pemberdayaan Masyarakat dan tema khusus yaitu Inovasi Pembelajaran" terhitung dari tanggal 03 Agustus-03 September tahun 2020 dilaksanakan di Desa Golo Wuas yang terletak di Kecamatan Elar Selatan, Kabupaten Manggarai Timur.

\section{Pengumpulan data}

Dalam menyusun laporan akhir program kuliah kerja nyata ini dilakukan pengumpulan data dengan berbagai teknik pengumpulan data yang ada, antara lain:

a. Pengamatan (observasi)

Teknik pengumpulan data berupa observasi dilakukan dengan cara mengamati dan menelaah secara langsung keadaan lokasi Kuliah Kerja Nyata (KKN), sehingga dapat menentukan program yang akan dilaksanakan dan menyiapkan segala kebutuhan teknis terkait program tersebut.

b. Wawancara

Selain melakukan pengamatan secara langsung, pelaksanaan Kuliah Kerja Nyata (KKN) juga melakukan wawancara sebagai salah satu teknik pengumpulan data dengan melakukan tanya jawab secara langsung dengan perangkat desa, masyarakat, pihak sekolah, dan warga Desa Golo Wuas. Pihak-pihak tersebut memiliki informasi yang dibutuhkan oleh mahasiswa yang merupakan pelaksana dalam program Kuliah Kerja Nyata $(\mathrm{KKN})$.

c. Internet Surfing

Internet Surfing dilakukan untuk mendapatkan data-data yang sifatnya ter-update, atau dapat dikatakan data-data terbaru agar data yang digunakan selalu bersifat aktual. 
2. Analis data

Data primer dan sekunder yang telah diperoleh dari pengumpulan data akan diolah dengan pola deskriptif kualitatif. Pada tahap pertama dilakukannya reduksi data, reduksi data merupakan proses pemilihan, pemusatan perhatian melalui penyederhanaan, pengabstrakan, dan transformasi data yang didapatkan, baik data primer maupun sekunder yang telah dipaparkan sebelumnya. Kemudian setelah reduksi data dilakukan, maka dilakukannya penyajian data yang berarti menyajikan data dalam bentuk uraian singkat ataupun bagan. Dalam penelitian kualitatif, penyajian data biasanya dilakukan secara naratif agar mudah untuk dipahami. Pada tahap terakhir dilakukannya penarikan kesimpulan dan verifikasi. Penarikan kesimpulan dalam penelitian kualitatif merupakan temuan baru yang disajikan berupa deskripsi atau gambaran yang awalnya belum jelas menjadi jelas.

3. Pelaksanaannya meliputi:

a. Sosialisasi guna menumbuhkan rasa solidaritas gotong royong antar warga, melakukan aksi bersih lingkungan kebersihan lingkungan;

b. Pelatihan penerapan pengajaran/pembimbingan kurikulum untuk mata pelajaran matematika pada peserta didik di sekolah dasar

c. Pelatihan terhadap kelompok tani dan masyarakat dalam pembuatan pupuk arang sekam dan pupuk kompos dengan memanfaatkan sumber daya yang ada di sekitarnya; dan

d. Partisipasi dalam pesta rakyat 17 Agustus di Desa Golo Wuas

e. Seminar Mini untuk meningkatkan pemahaman masyarakat tentang peran mahasiswa dan peran pemerintah desa dalam pemberdayaan masyarakat desa di bidang kesehatan dan energi listrik.

\section{HASIL DAN PEMBAHASAN}

Pelaksanaan KKN-mandiri disesuaikan dengan jadwal yang telah disusun sebelumnya dengan melalui tahapan-tahapan sebagai berikut:

Persiapan dan Pembelakalan

Kegiatan KKN Mandiri Univesitas Flores dimulai pada tanggal 31 Juli 2020 yang berupa pembekalan dari beberapa pemateri sesuai dengan tema yang akan diterapkan di masyarakat. Beberapa tema itu antara lain : Pertanian, Perencanaan sarana prasarana, Inovasi pembelajaran, Pengolahan data desa, dan Kewirausahaan. Kegiatan pembekalan ini dilakukan secara daring menggunakan aplikasi meeting zoom.

Pelaksanaan

Program KKN-Mandiri yang telah dilaksanakan oleh mahasiswa bersama dosen pembimbing dan masyarakat Desa Golo Wuas , Kecamatan Elar Selatan, Kabupaten manggarai Timur. Kegiatan ini dimulai dari tanggal 1 Agustus sampai tanggal 7 September 2020. Setiap minggu peserta harus melaporkan laporan mingguan yang berisikan rancangan program dan kegiatan yang telah dilaksanakan. Model pendampingan juga dilakukan secara daring menggunakan media e learning, dan classroom. Laporan yang dibuat dalam dua format yaitu PDF dan link Youtube yang berisikan aktivitas kegiatan. Laporan akhir dikumpul apda tanggal 7 september. Adapun kegiatan yang berhasil dilaksanakan dapat dilihat dalam dokumentasi berikut : 

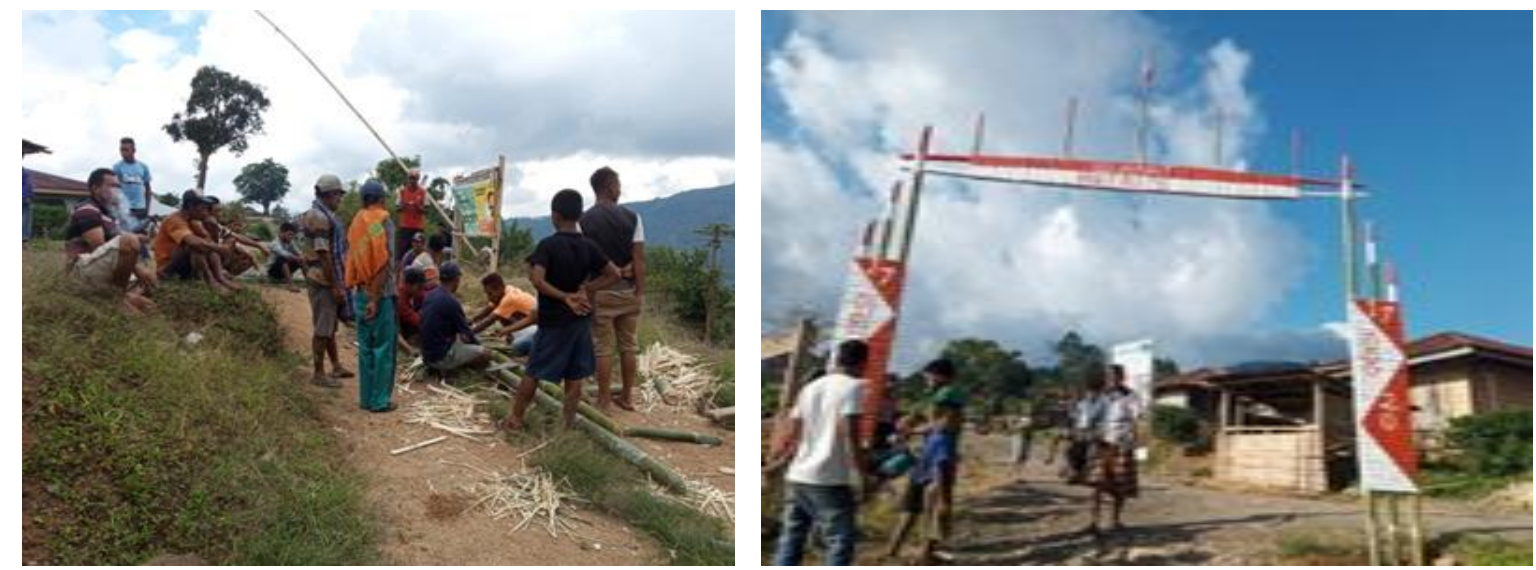

Gambar 1. Gotong royong membangun gapura desa dalam rangka HUT RI

Kegiatan KKN mandiri yang dilaksanakan pada bulan Agustus tentu akan terkait dengan momentum HUT kemerdekaan RI. Dalam rangka memnyongsong momen tersebut mahasiswa bersama dengan aparat desa mengajak masyarakat untuk bergtong royong membangun gapura dan umbul-umbul. Memanfaatkan bahan yang ada disekitar seperti bambu dan kayu mahasiswa beserta masyarakat mulai merancang dan membangun gapura dan umbul-umbul. animo masyarakat pada program ini cukup tinggi sehingga pekerjaan ini mampu diselesaikan dalam jangka waktu satu hari.
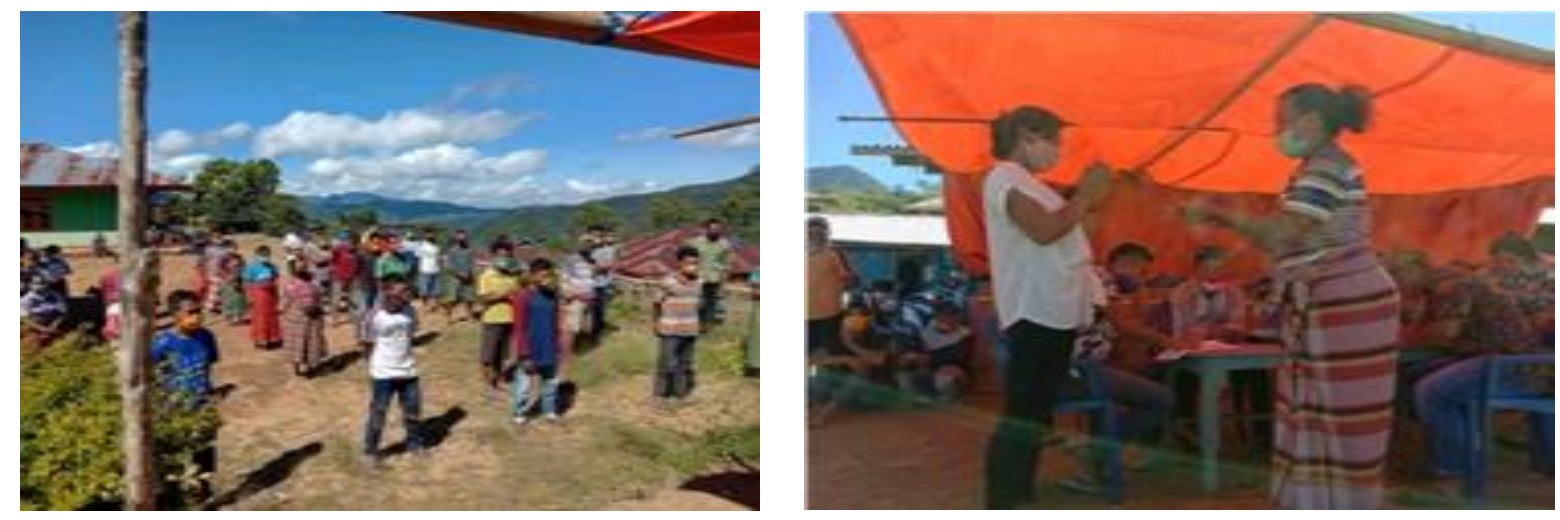

Gambar 2. Menjadi fasilitator bersama pemerintah desa dalam program bantuan tunai langsung

Pada masa pandemi ini salah satu program pemerintah dalam rangka meringankan beban ekonomi masyarakat terdampak virus korona, maka diberikan bantuan langsung tunai bagi keluarga yang tidak mampu. Mahasiswa bersama aparat desa mendata setiap kepala keluarga serta merancang model pembagian bantuan Langsung tunai. Selama pandemi kabupaten manggarai timur juga melaksanakan lockdown wilayah, dimana tidak ada aktivitas keluar dan masuk dari setiap wilayah,model lockdown local ini mengikuti fenomena yang terjadi di pulau jawa dimana beberapa desa melakukan lockdown local untuk mencegah arus keluar masuk warga atau pendatang (iJatengNewsID, 2020) Lockdown lokal ini tentu berdampak bagi perekonomian masyarakat desa yang semuanya memiliki mata pencaharian petani dan berkebun. Masyarakat sulit untuk menjual hasil panennya karena harus mematuhi aturan lockdown tersebut. Segala kegiatan ini tetap mematuhi aturan potokol seperti mencuci tangan menggunakan masker dan jaga jarak. Kegiatan pembagian bantuan dana langsung tunai ini berlangsung dengan lancar. 

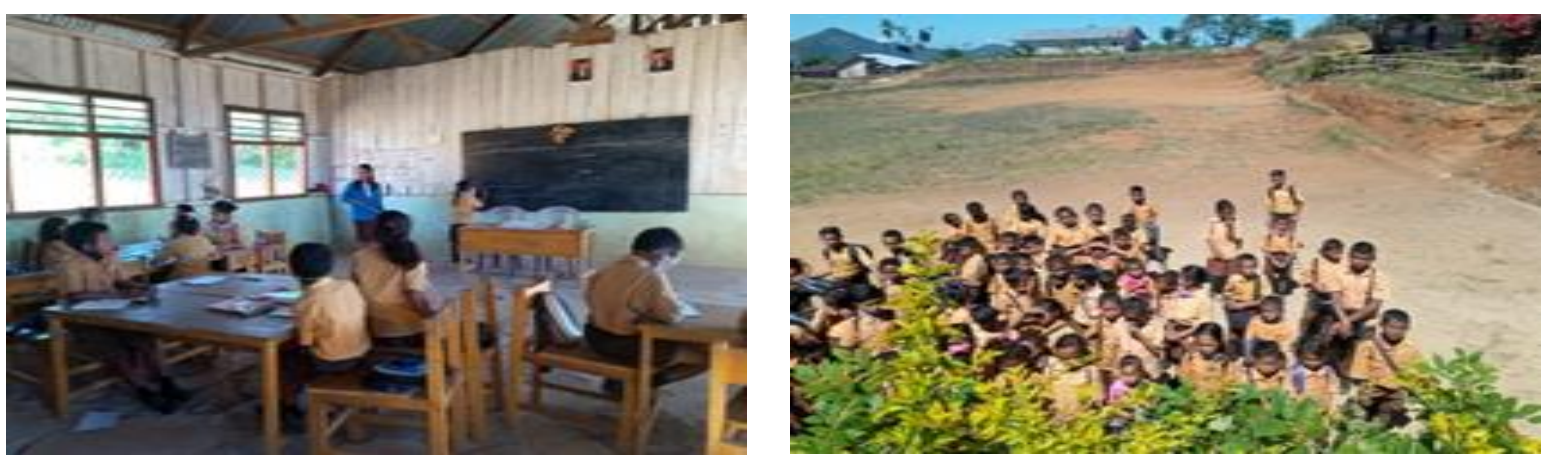

Gambar 3. Membantu guru mata pelajaran matematika pada peserta didik sekolah dasar di SD

Sebelum memulai kegiatan ini, mahasiswa KKN UNIFLOR memberikan surat izin untuk melakukan bimbingan kepada siswa di SDK Ndawang melalui kepala Desa Golo Wuas Bimbingan belajar merupakan program bagi siswa SDK Ndawang dan mahasiswa KKN UNIFLOR didalam kelas. Hal pertama yang dilakukan ialah melakukan observasi untuk melihat sejauh mana kemampuan siswa dan metode apa yang digunakan oleh guru-guru dalam melakukan KBM dan melakukan bimbingan kepada siswa.kegiatan ini dilakukan pada hari senin tanggal 24 Agstus 2020. Kemudian pada hari rabu 26 Agustus 2020 mahasiswa melakukan KBM didalam kelas dengan menggunakan metode yang berbeda dari sebelumnya yaitu mengajar menggunakan media pembelajaran yang kontekstual.
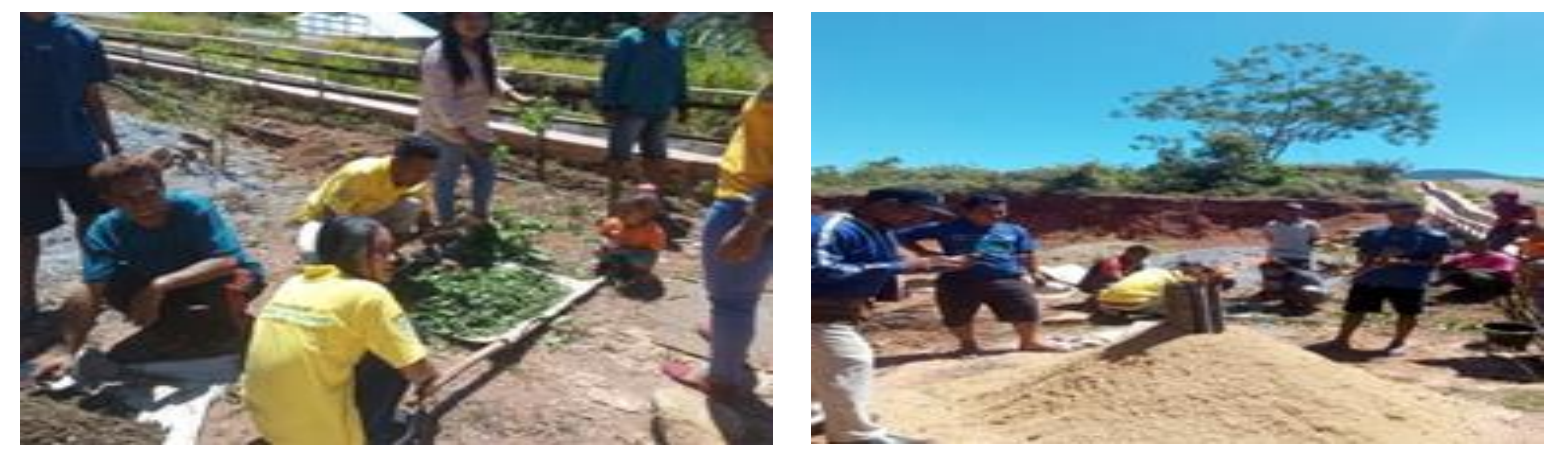

Gambar 4. Pelatihan pembuatan pupuk arang sekam dan pupuk kompos

Tujuan penyuluhan/praktek Pembuatan pupuk organik dan arang sekam untuk meningkatkan hasil produksi pertanian kelompok tani di Desa Golo Wuas. Arang diketahui memiliki fungsi sebagai pembangun kesuburan tanah (soil conditioning), selain itu arang juga digunakan sebagai pengganti kapur dan dolomit karena bersifat alkali dan dapat meningkatkan pH tanah yang masam dan juga sebagai sumber daya yang dapat diperbaharui (Noor Mirad Sari, dkk 2017). Arang mampu meningkatkan aktivitas mikroba perombak bahan organic sehingga populasi bakteri pongikat unsur Nitrogen akan meningkat. Tanah yang diberi pupuk arang sekam akan membangun kesuburan tanah baik secara fisik, kimia dan biologi (Widiastuti, Bonny Lantang, 2017).

Mitra dalam kegiatan pembuatan pupuk arang sekam dan kompos ini adalah masyarakat kelompok tani Desa Golo Wuas. Tahap pelaksanaan penyuluhan dimulai dengan cara membuat alat sederhana untuk proses pembakaran arang sekam, proses pembakaran arang sekam. Alat dan Bahan Alat-alat yang dibutuhkan pun mudah didapatkan seperti sekam padi, alat pembakaran (untuk alat pembakaran menggunakan kaleng bekas), koran atau kertas bekas, korek api, minyak tanah, arang, air dan tempat untuk menampung air, sekop, dan wadah penyimpanan pupuk yang sudah jadi (karung atau plastik). digunakan saat pelatihan masih 
tradisional. Pada Proses pembakaran arang dipilih lokasi yang agak jauh dari pemukiman di sebuah tanah lapang selain itu digunakan alas seng rumah bekas sehingga akan memudahkan pengambilan produk arang hasil pembakaran.

Pada pembuatan arang sekam, bahan baku arang arang yang diperoleh kemudian dimasukkan ke dalam pipa pembakaran, tambahkan sedikit minyak tanah, kertas bekas atau Koran bekas. Setelah beberapa menit perhatikan saat timbunan sekam padi terlihat menghitam, sekam yang masih berwarna cokelat dinaikkan keatas. Proses ini diulang sampai semua sekam berwarna hitam sempurna. Setelah itu siram sekam untuk mengehntikan proses pembakaran untuk menghindari terciptanya abu. Setelah itu bongkar gunungan arang kemudian masukkan dalam karung dan simpan di tempat yang kering.

Pembuatan kompos adalah sebagai upaya memanfaatkan potensi lingkungan sekitar berupa sisa sampah organik (Nunik Ekawandani, Alvianingsih, 2018). Metode yang digunakan dalam kegiatan ini yaitu pemberian materi dan demonstrasi. Pemberian materi tentang berbagai bahan sisa sampah organik disekitar lingkungan Desa Golo Wuas yang dapat digunakan sebagai sumber bahan baku pembuatan pupuk kompos. Bahan baku yang digunakan seperti hijauan/dedaunan, bonggol pisang, dan kotoran sapi, kotoran kuda, kerbau yang banyak terdapat disekitar desa. Campuran bahan tersebut kemudian ditambahkan dengan super decomposer, sekam padi, gula pasir, dan air. Transfer teknologi pembuatan pupuk kompos memberikan manfaat peningkatan pengetahuan warga tentang manfaat bahan sisa sampah organik sebagi bahan baku pembuatan pupuk kompos.
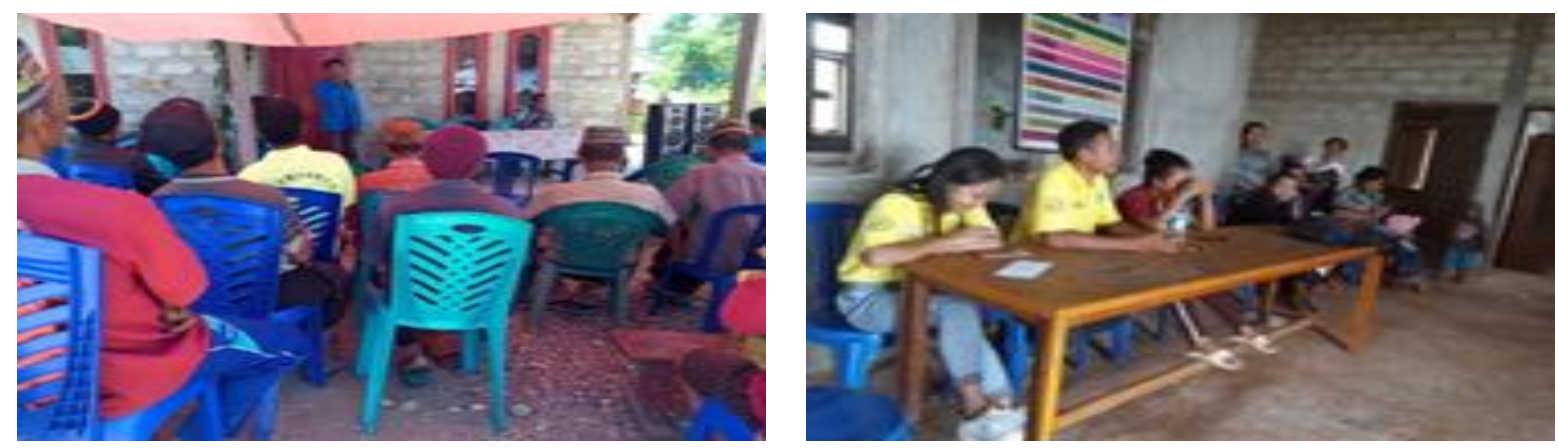

Gambar 5. Seminar mini pemberdayaan masyarakat desa dalam bidang kesehatan dan sosialisasi program Indonesia Terang

Seminar mini guna untuk meningkatkan pemahaman masyarakat tentang peran mahasiswa dan peran pemerintah desa dalam pemberdayaan masyarakat desa dalam bidang kesehatan. Selain itu pada kegiatan yang sama mahasiswa juga ikut membantu pegawai PTS guna untuk mensejahterakan masyarakat desa melalui program indonesia terang.

Pada kegiatan seminar ini masyarakat desa diberikan pemahaman terkait kesehatan agar selalu menjadi perhatian utama bagi masyarakat setempat. Masih kurangnya kesadaran masyarakat akan pentingnya kesehatan dikarenakan kurangnya sarana prasarana untuk mendukung program kesehatan, selain itu kurangnya tenaga ahli dari posdaya kesehatan dan kurangnya penunjang bantuan kesehatan dari puskesmas. Tujuan dari kegiatan ini adalah mahasiswa Ikut berpartisipasi dalam menumbuhkan kesadaran keluarga tentang fungsi-fungsi utama keluarga terutama fungsi kesehatan dalam membantu program pemerintah dibidang kesehatan dengan cara meningkatkan kesadaran masyarakat akan pentingnya kesehatan (seperti program pencegahan DBD dengan cara membagikan serbuk ABATE atau gerakan 3M 
(Novia Susianti, 2019)Gerakan 3M sangat efektif untuk dilaksanakn oleh masyarakat karena tidak membutuhkan biaya yang besar, kegiatan 3M itu antara lain :

1. Menguras, hal ini dilakukan dengan cara membersihkan tempat penampungan air seperti bak kamar mandi, drum penampungan air, tempat penampungan air minum dan lain-lain.

2. Menutup, langkah ini dilakukan dengan menutup semua tempat penampungan air yang disebutkan pada poin pertama

3. Mengubur, langkah ini dilakuakn dengan mengumpulkan semua barang yang tidak terpakai lagi atau sampah yang memiliki potensi menampung air sehingga menjadi sarang perkembangbiakkan nyamuk penular demam berdarah.

Selain itu kesehatan psikis juga turut diperhatikan yaitu dengan membantu pola fikir hidup sehat kepada masyarakat akan pentingnya kesehatan bagi tubuh, Membantu mengarahkan masyarakat untuk menerapkan cara hidup sehat dan bersih agar kesehatan tetap terjaga.

Pada sosialisasi terkait program Indonesia Terang, mahasiswa juga ikut membantu memberikan pemahaman terkait program yang ditawarkan kepada masyarakat desa yaitu pemanfaatn tenaga surya untuk menghasilkan listrik (ESDM RI, 2016) Manfaat yang diperoleh dari listrik bagi masyarakat desa bukan hanya berupa penerangan tetapi sebagai salah satu faktor yang diharapkan mampu mendorong perekonomian masyarakat desa nantinya sehingga taraf hidup masyarakat semakin membaik. Agar program ini bisa berjalan dengan efektif maka dibutuhkan kerjasama yang baik dari mitra dalam hal ini masyarakat selaku pengguna jasa nantinya, diperlukan keterlibatan atau pembentukan komite desa untuk menumbuhkan rasa kemepemilikan dan tanggung jawab dalam hal pengoperasian dan perawatan sistem kelistrikan jika nantinya program ini terlaksana di desa Golo Wuas.

\section{SIMPULAN DAN TINDAK LANJUT}

Berdasarkan hasil pelaksanaan pengabdian KKN mandiri, maka diperoleh beberapa kesimpulan dari kegiatan ini adalah : (a) pelaksaanan KKN di desa jika dilaksanakan pada bulan Agustus peserta lebih banyak terlibat dalam kegiatan bakti sosial karena berkaitan dengan momentum HUT Republik Indonesia; (b) Program KKN Mandiri ini mampu mentransfer beberapa pengetahuan atau teori yang dipelajari bangku kuliah untuk diterapkan di lapangan (masyarakat);(c) Keberhasilan program KKN di desa Golo Wuas bisa terlaksana berkat dukungan penuh dari aparat desa serta masyarakat ; (d) melalui program KKN ini bisa digali potensi-potensi lokal yang ada untuk dimanfaatkan dalam meningkatkan taraf hidup masyarakat desa. Adapun saran atau tindak lanjut program KKN meliputi : (a) Perlu ada dana stimulus dari kampus agar memudahkan pelaksanaan program KKN; (b) sebelum program KKN dilaksanakan perlu ada koordinasi antara pihak Universitas dengan Desa untuk menggali profil atau gambaran umum desa tersebut agar program yang dirancang lebih tepat sasaran dan berkelanjutan.

\section{DAFTAR PUSTAKA}

Syardiansah, S. (2019). PERANAN KULIAH KERJA NYATA SEBAGAI BAGIAN DARI PENGEMBANGAN KOMPETENSI MAHASISWA (Studi Kasus Mahasiswa Universitas Samudra KKN Tahun 2017). JIM UPB (Jurnal Ilmiah Manajemen Universitas Putera Batam), 7(1), 57-68. doi:10.33884/jimupb.v7i1.915 
Sari, N. M., Lusyiani, L., Nisa, K., Mahdie, M. F., \& Ulfah, D. (2017). Pemanfaatan Limbah Sekam Padi untuk Campuran Pupuk Bokashi dan Pembuatan Biobriket sebagai Bahan Bakar Nabati. PengabdianMu: Jurnal Ilmiah Pengabdian Kepada Masyarakat, 2(2), 90-97.

Widiastuti, M. M. D., \& Lantang, B. (2017). Pelatihan Pembuatan Biochar dari Limbah Sekam Padi Menggunakan Metode Retort Kiln. Agrokreatif Jurnal Ilmiah Pengabdian kepada Masyarakat, 3(2), 129-135.

Ekawandani, N. (2019). EFEKTIFITAS KOMPOS DAUN MENGGUNAKAN EM4 DAN KOTORAN SAPI. Jurnal TEDC, 12(2), 145-149.

Susianti, N. (2019). Strategi Pemerintah dalam Program Pemberantasan Demam Berdarah Dengue (DBD) di Kabupaten Merangin Provinsi Jambi. Buletin Penelitian Sistem Kesehatan, 22(1), 34-43.

ESDM R., (2016). Program Indonesia Terang, Pemerintah Akan Berikan Insentif. Kementerian Kesehatan Republik Indonesia. Diakses 2 September 2020, pada https://www.esdm.go.id/id/media-center/arsip-berita/program-indonesia-terangpemerintah-akan-berikan-insentif

BPS Manggarai Timur. (2020). Kecamatan Elar Selatan Dalam Angka 2020, diakses 2 Agustus 2020, pada https://manggaraitimurkab.bps.go.id/

iJatengNewsID. (2020). Sejumlah Desa di Kendal Lockdown Lokal Cegah Covid-19, Tamu Dibatasi 30 menit. Diakses 8 Agustus 2020, https://jateng.inews.id/berita/sejumlahdesa-di-kendal-lockdown-lokal-ce 